\title{
Austin's mantle, or who's (not) afraid of John L. Austin? On 50 years of speech act theory, and how Rajan saves J.L. Austin from himself and others \\ O manto de Austin ou quem (não) tem medo de John L. Austin? Sobre os 50 anos da teoria dos atos de fala e como Rajan salva Austin de si mesmo e de outros
}

Jacob L. MEY (University of Southern Denmark - emer.)

\section{ABSTRACT}

The article places the person of Professor Kanavillil Rajagopalan within the context of his many years of research and teaching at various universities in Brazil. It is argued that his efforts to advocate a new approach to linguistics, based on the notion of 'speech acts', was not always well received by the practicing linguists of his day and age. Moreover, while researching the foundations of speech act theory from its inceptions, it became clear to Rajan that the doxa of 'Searle merely codifying and cleaning up Austin's somewhat unruly legacy' does not hold. The common opinion represented by this view does injustice, both to Searle as an independent thinker and to Austin as an original philosopher in his own right, who not just speaks through a Searlean mouthpiece. In particular, people have not paid attention to an essential element of the Austinian oeuvre: his persistent distancing himself from all iron-clad and rigid theorizing; in addition, Austin's humor played always a big role in his presentations, both orally and in writing. Rajan thus creates a more nuanced picture, both of the theory itself and of its two great protagonists, Austin and Searle.

Key-words: Speech Acts Theory; John L. Austin; Kanavillil Rajagopalan. 


\section{RESUMO}

O artigo coloca a pessoa do professor Kanavillil Rajagopalan dentro do contexto de seus muitos anos de pesquisa e ensino em várias universidades do Brasil. Argumenta-se que os seus esforços para defender uma nova abordagem para a linguística, com base na noção de "atos de fala", não foram sempre bem recebidos pelos praticantes da linguística de sua época e idade. Além disso, pesquisando os fundamentos da teoria dos atos de fala desde seu início, tornou-se claro para Rajan que a doxa de 'Searle apenas codificando e limpando o legado um pouco desarrumado de Austin'não se sustenta. A opinião comum representada por esse ponto de vista é uma injustiça, tanto para Searle como um pensador independente, quanto para Austin como um filósofo original em seu próprio direito, que não só fala através de uma boca searliana. Em particular, as pessoas não prestaram atenção a um elemento essencial da obra de Austin: sua persistência em distanciar-se de toda teorização ferrenha e rígida. Ao contrário, o humor de Austin desempenhou sempre um papel importante em suas apresentações, tanto oralmente quanto por escrito. Rajan, assim, cria uma imagem mais diferenciada, tanto da própria teoria como de seus dois grandes protagonistas, Austin e Searle.

Palavras-chave: Teoria dos atos de fala; John L. Austin; Kanavillil Rajagopalan.

\section{Introduction: Afraid of John L. Austin? Not Rajan! But neither was Searle...}

In one of his recent articles, this dear colleague Professor Kanavillil Rajagopalan (henceforth Rajan) quotes John R. Searle to the effect that

"[O]ne of the reasons why the subject of speech acts is so much fun is that you don't have to worry about what all the great figures from the past said, because most of the great philosophers had no theory of speech acts." (John R. Searle, as quoted in Nerlich and Clarke (1994: 440; the quote itself is from Rajagopalan (2000: 246)).

To which I only can add: Speech act theory would have been even more fun, had these two great figures from the present, Rajan and Searle, 
been able to participate in our 'colloquium doctum' on the nature of speech acts - and, of course had we also been able to conjure up the spirit of John Austin, like the witch did for King Saul in the mountains of En-Dor, when she called up Samuel the prophet - though with less disastrous consequences! (1 Sam. 28). As it is, we'll have to imagine this debate and participate in it by proxy, each of us at their leisure, by consulting Rajan's article from which I just quoted: "On Searle [on Austin] on language", as well as by joining me here today in the festive celebration of which my talk is a small part.

In the quotation above, note especially the words "on Austin on language". This could well serve as a motto for Rajan's entire life-work, as it was spent in the service - not just of language, but of language's users, and not only the linguists, both theorists and practitioners, but first and foremost the usual man or woman in the street.

The festive occasion which is the immediate reason for my appearing here before you, is to celebrate Rajan, this linguiste extraordinaire, and his many years in the service of the 'Word that has become Act' - not just 'in the beginning', as Goethe had it ("Im Anfang war die That"; Faust I: 354), but comprising the entire span of 'languaging' (to borrow the Chicago anthropological linguist Paul Friendrich's felicitous neologism for our pragmatic/linguistic acting).

\section{Of mantles and prophets}

Elsewhere in the earlier quoted article (2000:356), Rajan embarks on a daring flight of Biblical metaphor by introducing the well-known conceit of Elijah's mantle (2 Kings 2). Here, I will leave aside the question whether in our case, the mantle was wrenched from its owner, or bestowed on its new bearer by an appropriate act of investiture. In the Biblical story, when Elijah's apprentice, Elisha, utters the wish to be invested with "a double portion of the spirit" of his master, upon the latter's "being taken" (2 Kings 2:9), Elijah says it is not for him to make that assignment. However, there will be a sign: when Elijah is taken up by the Lord, and Elisha is a visual witness to that event, the heritage of the mantle is his, and he will be the new Nr. 1 Prophet in Israel. 
When the heavenly chariot arrives, Elijah is taken "in a whirlwind", being "parted asunder" from Elisha by the fiery horses and "going into heaven" in full sight (2 Kings 2: 11). Consequently, Elisha realizes that the time has come for him to take a drastic step towards his new future. Courtesy of the whirlwind, the departing prophet's mantle (for which he of course has no longer any use) drops to the ground, unscorched by the chariot's flames. Elisha promptly rents his own garment in two, grabs the prophet's mantle, and puts it over his head. Not satisfied with the first part of the prophecy having been fulfilled, he proceeds to the river Jordan to test his new dignity, by replicating the miracle he had seen his master perform: rolling up the mantle, he beats on the waters while uttering "Where is the Lord God of Elijah?" - upon which the waters part, allowing Elisha to pass on to the other side.

One may wonder at the new prophet's sheer confidence in his mission (some would call it 'cheek'), but Elisha did in fact pick up the mantle according to a pre-destined script. Once a prophet, he follows in his master's footsteps, in particular by inveigling against all the false prophets in Israel (his competitors, one could say) and removing all the traces of idolatry that he can identify across the land.

From the Biblical story, it appears that taking up a mantle is not without risks: mantles oblige. But exercising the power that is inherent in the prophetical function, symbolized by the mantle, also requires a certain exercise of judgment, and Elisha was not always up to this score, as when he did in forty two children, just because they had mocked him, or when he performed a sorcerer's trick by making a borrowed axe-head of cast iron float up in the river after one of his servants had lost it (2 Kings 6: 6).

To come back to Rajan, there can be no doubt that he himself never was a mantle-bearer, or aspired to be a prophet in the Old Testament sense; he never rent his garments, either (as far as I know, Rajan is always immaculately dressed), or molested small children making fun of him (one could not imagine a gentler man than Rajan!). Rather, I see Rajan as a critic of grabbers and bearers of mantles. Of which the next section of my paper will treat. 


\section{A prophet in his country?}

When Rajan started his (shall we say 'prophetic'?) mission, the theory of Speech Acts was still in its infancy. I recall, how in 1971, I was accompanying (now Sir) John Lyons (then a rising star on the British linguistic firmament) across the campus of the University of Texas to the Linguistics Department, where he was giving a lecture. On our way from the parking lot to Calhoun Hall (where the linguists just had moved), one of my colleagues, a young professor named Emmon Bach, joined us and introduced himself to the distinguished guest ("Call me Emmon - may I call you John?"). John was preparing a lecture on the 'hot' subject of speech acts, and referred to a book he recently had acquired: John R. Searle's 1969 Speech Acts. One thing I remember vividly from that peripatetic conversation is that at a certain turn, the question arose of the importance and relevance of Searle's book. To Emmon, this was clearly a matter of some doubt since, as he said, "this is just not linguistics" (he may have considered it some kind of philosophical meditation on linguistic matters - recall that Searle's subtitle reads 'An essay in the philosophy of language'). And honestly, I don't think that at that time, any linguists in their right minds would consider a work like Searle's, and by implication, Austin's own theories, to be part and parcel of, or even relevant to, linguistics: a discipline which, at the time of speaking, in much of the US was "grappled by hoops of steel" (Hamlet, Act 1, Scene 3) to the then current Chomskyan generative framework.

No wonder then, either, that Rajan experienced some difficulty going against that current by advocating a new way of thinking on matters linguistic. His orientation was from the very beginning holistic (even avant la lettre), and though he never officially affiliated himself with any 'movement', decidedly pragmatic. By this, I mean that for him, the language user was up front, the grammarian being assigned a lower rung on the ladder of importance.

The work of John Austin, in freeing the study of language from the straitjacket of narrow linguistic description, clearly was of value for him here; but Rajan never was a 'doctrinaire Austinian' (an expression which, at the end of the day, is an almost laughable oxymoron anyway). The same could be said, a fortiori, of his relationship to Searle and the 
other post- and neo-Austinians (I'll come back to this question later in my contribution). Rajan's interest was captured by the big issue of 'what people can do with language' - a roundly Austinian theme, of course, but also one that transcends the framework laid out by the Master himself, and looming larger than life, even after the latter's premature departing this world (though not in any fiery chariot!).

From the very beginning, Rajan's attention was focused on concrete issues of language use and abuse, its users and its abusers. There were the problems having to do with second language teaching and learning; the issues involving native first languages and their users - issues that were still frowned upon by the scholarly elite, except in the context of linguistics proper: phonetic and morphological analysis, grammar-building for grammar's own sake, theoretical syntax, and abstract semantics - all with a view to universal analytic descriptions illuminating the 'human mind' from the perspective of the (mostly Western-oriented) linguists and linguistic philosophers.

In this connection, Rajan's interest in questions of translation needs to be mentioned. Being himself a bi-, tri- or even multi-lingual language user, he was from early on confronted with the necessity of expressing the "same" thoughts in various idioms, while preserving the original utterance's content and the utterer's intention.

Already here, the whole enterprise of translation risks to founder on some presuppositional skerries: Who says that we can 'transfer' a content undivided and whole from one language to another? Take the early Lutheran missionaries in Greenland: they faced a language and a life style that were so utterly different from common Western thinking, speaking, and acting that they were at a loss to find Greenlandic equivalents for their own everyday expressions and concepts, such as those denoting substances like 'bread' - common to the European and other 'civilized' languages they were familiar with, but totally absent from the Greenlandic mind.

But the problem goes even deeper. By transmitting one's own cultural and intellectual content to a foreign language, while clothing it in wording that is as close as possible to one's original intention and formulation, one necessarily influences the recipients, the speakers of that other language, by making them first adapt to one's own 
particular linguistic and mental format, and in the end forcing them to adopt it as their own (as it happened in the case of the $18^{\text {th }}$ century Greenlanders).

But actually, we need not go back in time, or out in space, to illustrate the problem. A modern parallel is encountered in the (often loosely handled) notion of 'domain loss', by which entire areas of people's lives are said to be 'sold out' to a foreign culture and language - easily the most crucial issue (along with the looming loss of living habitat) that countless users of minor and minority languages face.

Consider for instance the wholesale takeover of the domain of computer theory and applications by English-language expressions, often not even phonetically or morphologically assimilated to the borrowing idiom. Moreover, this particular trend seems to have accelerated over time: thus, for instance, when the first professional terminologies, those for dentistry and engineering, were introduced into Japanese contexts, there was a strong feeling that one had to find proper Japanese (or Sino-Japanese) equivalents, even for the most arcane technical terminology. But a century later, among more recent 'acquisitions,' one encounters nary a Japanese term, as everything has either been anglicized or outright borrowed - which of course doesn't mean that such 'English' terms therefore are intelligible to native speakers or readers. Both in the phonetic realization and graphical representation of such loans, the laws of the borrower reign supreme, as everybody knows who has tried to decipher Japanese katakana transcriptions of English words, or decode the associated Japanese pronunciation of 'English' terms (as in karaa terebi for 'color TV'). (I recall how I was completely lost when, in the introductory presentation of a Japanese institution of learning, one of the women members declared she was shinguru - 'single'!)

\section{4. 'Traduction' and tradition}

Let's now return to Rajan and his interest in matters of practical language use. In current discussions, there is a focus on a particular field of use, the metaphorical universe characterized by so-called 'domains' and 'takeovers'. It is easy to see that there are two sides to 
this metaphoric medal, as there are to any other. On the one hand, to use a term originally coined by the Chicago anthropological linguist Paul Friedrich, there is the foreign 'languaculture' impinging on our 'national(ist)' territory; on the other hand, there are the users who reach out from under their linguistic hedges to pick the fruits of other cultures. A condition for the latter to happen is of course that the pickers acquire a second language (or even a third, fourth, etc,); rather than in a fit of xenophobia condemning those $\mathrm{L} 2, \mathrm{~L} 3, \mathrm{~L} 4, \ldots$ as a danger to (perceived) national or personal identities, let us look at the benefits that accrue from acquiring a 'second opinion' on even the most mundane matters of life and work.

Consider the case of my Danish friend Ide, who spent a year in a monolingual, post-High School educational establishment in Germany. She told me that the contact with the foreign languaculture actually opened her eyes and ears to possibilities in her own language that she never had thought were there. She even started to write poetry (something she had never done before) - but in German, not in her own language, Danish! It is as if the exposure to the L2 loosened the conceptual hold that her first language had exerted on her mental facilities.

As Rajan has expressed it: rather than cleaving to our own languaculture, we should opt for translating it, and have it translated. Adopting Rajan's Portuguese wording (his wordplay cannot be replicated directly), we should opt for translation, tradução, rather than merely jealously guarding our own tradição, tradition (Rajagopalan 2003). Such a 'tra-duction', literally a 'carrying over' from language to language, from culture to culture, in both directions, teaches us to have a distancing look at our own languaculture; in other words, to assume what often has been called a 'critical' linguistic attitude.

\section{Rajan, a 'critical linguist'}

The area of 'Critical Linguistics' has perhaps become best known through the efforts of Teun van Dijk (a Dutch linguist now affiliated with a Catalan university). Both in his numerous own works and not least through the establishment of an international community embodied 
in a listserve called 'Critics' since the mid-1990s, van Dijk has been a forceful advocate of the critical dimension in language studies. Others had been working in the same critical 'tradition' (excuse the oxymoron), such as the group around Norman Fairclough at Lancaster, who dubbed his approach 'linguistic awareness' (later renamed 'critical discourse analysis'). Rajan's agenda as a critical linguist (both in his 2003 book and elsewhere) is basically the same as, or at least similar to, the agenda pursued by Fairclough and many other workers in the field. The main difference is that Rajan combines his research with his own experience of being a sometime member of a particular segment of the world's population, viz., speakers of non-hegemonic idioms, the under-represented, but over-oppressed minorities. One of the immediate effects of this condition is that in situations of language inequality, the more powerful language users manage to put their agenda up front. That agenda contains, as its first (but often unnoticed) item, the language of the meetings, workshops, seminars, round tables, submissions, posters etc.: in the majority of cases, that language is English.

Whereas a mere fifty (or even a hundred) years ago, English was one of a handful of possible 'world languages', in the sense of being accepted as valid transactional means in international contexts, the situation today is such that even in environments where the majority of speakers are not (by birth or acquisition) Anglophones, English is adopted as the lingua franca of the event. Even in cases where the official languages of a conference include idioms other than English, the amount of interaction between speakers of those other languages and their anglophone colleagues is minimal. And since the English world represents power, also in other respects (economic, social, etc.), the other-language speakers usually gravitate towards the English 'center' from their 'peripheral' positions, in order to be where the action is.

Rajan deconstructs the insidious, self-moving mechanism behind these happenings by pointing out that the use of English as a 'postcolonial language' by no means is neutral, in the sense that it provides access to everybody on the same footing. English, as the prime language of the erstwhile colonizers, carries with it the stigma of the colonialist mentality, by which the original inhabitants of a colonized country, by definition speakers of other languages, are deemed inferior to the territorial expanders, the invaders. 
Such has been, and still is, the situation in much of the colonized world even today; it also is, and has been, the everlasting trauma of all colonized peoples, from the Greek-styled bárbaroi to our days' 'primitive' peoples all over the world. As an old classmate of mine (a long time immigrant to Australia) once remarked, commenting on the situation of the aboriginal dwellers in that country: "Look at what those 'abos' achieved in all those years they lived on this continent: they never produced a single invention, they never developed any technology, they just kept on speaking their own languages and following their old ways, and where are they today? Exactly where they were 30,000 years ago, but probably a lot worse off, compared to even the poorest of the 'whitefellas' [white Australians]!"

An attitude like this is of course not one that many linguists would embrace; even so, I recall how one famous anthropological linguist, on welcoming his Ph.D. students back from 'the field', used to preface his greeting with the dreaded question: "Did you get the language? All of it?" - as if the language in question were a commodity that could be extracted from 'the field' in ways similar to the extraction of a barrel of crude from an oil field.

Such ways of practicing linguistics and doing linguistic research are of course everything but 'critical', inasmuch as they bypass the original users, the speakers of the commoditized language, who are only allowed in to further the linguists' professional and personal aims, or to figure as props, when the linguists need to show off their analytic capabilities. True, some amongst the latter have recently started to feel a moral responsibility towards the native language users they have exploited in this way, and have begun to give them credit (by naming them, or even thanking them for their input); in some cases, there has been an effort to assist the 'fieldworked' indigenous subjects also materially. But the critical questions remain: How can the linguist in the field contribute to an equitable, societally oriented analysis of the context (linguistic and otherwise) in which the tribal or colonized people live? And: How can these people's life situation be ameliorated without offending the subjects' self-estimate and self-worth? Colonialism raises its ugly head everywhere; no matter what one does (or tries to do) in 'the field', the linguists' real or imagined superiority will always be a stumbling block on the road to real and effective emancipation of the enslaved, 
be they subjugated camponeses in the Nordeste of Brazil, or expelled tribal folks scraping together a living in some urban encampment in São Paulo, far away from their traditional modes of subsistence and alienated from their own language and culture.

\section{6. "The voice of one calling out in the desert" (St. John 1: 23)}

Rajan's contributions to a critical view of linguistics have not only been of the kind I just mentioned: critical of the oppressive society that uses language as a tool of enslavement. More broadly speaking, he has also 'emancipated' linguistic thinking itself, both by denying the exclusive validity of the generative paradigm due to Chomsky, and by warning against essentialist interpretations of Austin's valuable insight: that language is for humans to do things with.

Rajan had to carry on this good fight on a double front: on the one hand, his ways of thinking were not at all appreciated by the 'real' linguists in his surroundings; on the other hand, he had to combat the rigid codification and regimentation that speech act thinking had been subjected to, especially in the first decades after Austin's demise.

It has been argued by some that Austin left behind a rather shoddy legacy of half-baked thoughts and unproven concepts; the land he had tilled was left more or less waste, and somebody had to do a cleaning up. And that somebody turned out to be John Searle.

Notwithstanding the merits of Searle's work (which Rajan was the first to recognize on its own premises), there are always dangers inherent in a strict codification of a great thinker's luminous inspirational thinking (ceteris imparibus, think of the ways the Christian tradition has (mis)managed the interpretation and teaching of the Gospel). Here, the (by now perhaps a bit over-worked) Biblical picture of the prophet Elijah's disciple dividing the waters by wrapping together his master's mantle and smiting the river receives a new actuality. By separating out what Austin had said and written (and possibly intended) from what later generations, mostly following Searle, often have attributed to him, Rajan has contributed to keeping the spirit of speech acting alive against the often dead and deadening letter of maxims, rules, implicatures, and 
so on - not even mentioning truth conditions or relevance principles and all their discontents...

As I said, this is not to imply that Rajan did not recognize the importance of Searle's work 'on Austin' (as well as that of other 'post-Austinians', such as Grice or Levinson); quite the contrary, he acknowledges that "Searle's contribution to the theory he inherited is very remarkable and original" (Rajagopalan, 2000: 353). Even so, Rajan has been one of the few (and certainly one of the first) that drew attention to certain discrepancies between the Master and this particular Disciple: many of the notions that since have become incorporated in the canon of Speech Act Theory were not originally due to Austin (or due to him only in a remote way). As Rajan expresses it, "Searle did develop Austin's thoughts in ways his mentor would most probably not have even imagined"; consequently, the way the theory was codified in the Searlean tradition was "at loggerheads" with the original Austinian conception (Rajagopalan, 2000: 353).

\section{Who owns the language?}

It is not my intention here to decide the Searle-Rajan discord in favor of one authority or the other; instead, let me remark on another aspect of the discussion that deserves to be mentioned. When Rajan dons his other mantle, that of the eminently critical linguist, he refuses to subscribe, let alone kowtow, to the common opinion, the established doxa, to use a Bourdieuian term. This trait is so characteristic of Rajan that I want to devote some space to the role he plays in another case of the same ilk as the one discussed earlier, namely, the discussions raging in contemporary Brazil on the future of Portuguese in the face of a threatening invasion of 'estrangeirismos', locutions or words that are borrowed from other languages (especially English) and which sometimes 'expel' a local equivalent, to the inconvenience of the native users and to the detriment of their consciousness as competent users of their own idioms.

The phenomenon is of course not limited to Brazil; earlier, I have alluded to the alleged danger of 'domain loss' that has been a point of recent acrid debate in many West European countries. Here, 
as elsewhere, Rajan aligns with the users of language, as embodied in the 'common man/woman', against the self-professed experts in matters of language: the linguists, who mostly fail to see how their own stance is inextricably bound up with their position as 'keepers of the word', sanctioned and anointed by some instance of higher societal ownership.

What such experts fail to see is the way language is being used as an instrument of oppression and repression (Mey 1985): the expert functions not only as the oppressive guardian of linguistic knowledge, but as a repressive gatekeeper who denies access to those who do not qualify along the lines sketched out by the dominant keepers of the knowledge. According to the latter's ideology, there is just one correct language, which must be the norm for everybody to accept, on the peril of being excluded from the speaking community.

As Rajan remarks (2003), going against classical speculations about the purity of human language, there is no such thing as a 'pure' idiom (compare the comparatist Max Müller's (1881) famous dictum, "There are no mixed languages" (Es gibt keine Mischsprache; quoted by Ferreira, 2004), but also the dialectologist Hugo Schuchardt's equally famous (1884) pronouncement "There are no completely non-mixed languages" (Es gibt keine völlig ungemischte Sprache)). Purity in matters linguistic represents an ideal that was borrowed by the linguistis working in the tradition of the Enlightenment, along the same lines of thinking that considered mathematics as the only true expression of the human spirit, and the mathematical formula the only 'fool-proof', allperfect human way of expression, as Leibniz thought, and many later thinkers with him - even to the point that God was believed to be able to speak to humans (if ever He did so directly) only in the language of mathematics! (Rajagopalan 2005: 14)

In all of this, Rajan's critical spirit makes him see that the human language is not just a social phenomenon - which in itself is an insight far superior to one considering language only as a set of grammatical rules and/or well-formed expressions. Rajan goes further and asserts that languages are "social possessions" (2005: 26); that is to say, languages are owned by humans, who in the end are the ultimate subjects and objects, origins and endpoints, of all use of language. 
Language is social in this double sense: it is created and maintained by the community which is its 'matrix'; conversely, language is the 'cradle' into which the human is born and nurtured until he or she steps into character as the language's lawful user and possessor.

In recent times, it has become popular to consider social phenomena through the lens of the economy, in particular the marketplace. The earlier mentioned French sociologist Pierre Bourdieu has written about 'social capital'; before him, the Italian philosopher and linguist Ferruccio RossiLandi had characterized language use as a case of 'market interaction' (see Mey 1985; 2002 for references and critique). What is missing in these metaphors and their application to the case of language is a realization of the fact that there is no such thing as a 'free linguistic market': marketing interests are always subject to the governing forces of society, who will proclaim 'freedom' only when it is in their own economic and social interest. In economic interchange as in linguistic interaction, however, true freedom can only be guaranteed if certain rules are established to warrant a free exchange of possessions (material or social), by giving the needed protection to market partners with less clout.

Recognizing that the linguistic community is not a homogeneous, idealized whole, but consists of many diverse segments, each with their own power structure and depending on the other sectors in various ways, is a first step towards establishing a linguistic democracy, where the individuals' freedoms are guaranteed and their possessions (including social possessions like language) are safeguarded. As Rajan has expressed it, we need to strike a balance between extreme, unbridled Herderian chauvinism ('one nation, one country, one language') and a laissez-faire attitude that believes in the healing powers of a 'socially responsible' linguistic market (Rajagopalan 2005: 23).

\section{Conclusion}

In my concluding remarks, I intend to deviate a bit from the usual, established format of concluding a paper: recapitulating its main themes and issues, and then adding some well-considered admonitions. Instead, I want to highlight an aspect of Rajan's work that so far, has gone underrepresented: the personal dimension. 
What is it that makes Rajan, Rajan? And how do we position ourselves in relation to this remarkable figure, truly a critical "voice of one crying in the wilderness" (St. John 1: 23)? Naturally, critics are not beloved by the criticized, and it is also true that "no prophet is accepted in his own country" (St. Luke 4: 24). Be that as it may, it seems eminently suitable that we today should honor this prophetic spirit, who has carried the torch of pragmatics into uncharted territory, and kept it burning for so many decades. By infusing the Austinian paradigm with a solid dose of social responsibility and communityoriented thinking, he has placed language studies, theoretical as well as practical, on a safe societal footing, and has established a beacon of light in the turbulent waters of chauvinist oratory.

I have chosen, as the title of my talk, the words "Who is (not) afraid of John L. Austin?" Some may find this a cheap, well-worn pun on a certain celebrated piece of literature and its author; but I want to put more into it than just a fleeting allusion, or even a "glib performance for immediate consumption", as the Greek historian Thucydides has it (Hist. I: 22.4). However, as the very use of the word 'afraid' may conjure up a possible misunderstanding, perhaps a better expression could be 'concerned'. What Rajan has been most concerned about in his professional life, and hopefully will be so into a distant future, is a just measure of belief and critique: a belief in the positive potential of a theory, combined with a critical, open eye for its limitations, whether built into the theory by its founder(s) or subsequently introduced by its defenders or opponents.

I see this 'just measure' abundantly demonstrated in the way Rajan prophetically divided the waters between Austin and Searle; in his critical view of much of modern linguistic theory and practice; or in his judicious argumentation against the 'language engineering' that so often is substituted for a decent language policy in the halls of our governing bodies and educational institutions, as well as in the public debates on education. Rajan has resisted all efforts to essentialize those debates as a matter of 'love it or leave it' (originally said of conscientious objectors to the Vietnam war, in an effort to question their patriotic loyalty), in accordance with the late Robert A. Hall, Jr.'s admonition to users to 'leave your language alone' - a plea for absolute laxity in matters of language policy (Hall 1950). Instead, Rajan advocates an approach 
based on the need of a dialogue between at times diametrically opposed parties: the theoretical linguists who despise everything that smacks of 'applied', and their applied colleagues, who deal with the everyday business of language use - a dialogue in which the conflicting parties of necessity share a practical interest with their adversaries, when it comes to 'doing things with language'. Rajan's successful efforts towards a 'unification' of the different obediences have effectively cemented his reputation as a 'bridge-builder', not only between theoretical and applied linguistics, but far into their respective hinterlands, as only a 'grand old statesman' (not just a 'pontifex', but indeed a prophet) of pragmatics could.

Let me finish my contribution by giving you a personal impression of this great man, based on our acquaintance and friendship of more than three decades.

When I think of Rajan as I know him best, as a presenter at scientific conferences and as a participant in debates on language and its use, what comes up is the skilled debater with an incredible backup facility of accessible facts and theoretical insights, to be marshaled at the drop of a hat; but also the warm-hearted defender of human language rights and the status of minority language users. Here is one such instance of a typical Rajan-esque performance.

At a recent international pragmatics conference, I had organized a panel, which included Rajan as a discussant. Unfortunately, at the last minute, one of the participants had to cancel his presentation owing to a family emergency. Rather than let the panel slot go unused, I approached Rajan, and asked him if he could take over and fill in; in return, I would take on his role as a discussant in the debate after the panel's last presentation. Rajan didn't hesitate a second; he only asked that I give him a few minutes to prepare - which he got, as we were still well ahead of the slot in question. I noticed how Rajan sat down at a table in the hallway, took out his well-worn notebook and proceeded to scribble on a few leaves of 3"x 6" format, which he then carefully tore out and stuffed into his breast pocket. When the time came for him to speak, he barely glanced at his notes, but delivered a complete, wellinformed, and entertaining lecture on the subject of second language acquisition and its various roadblocks and perils. He spoke for about 
15 minutes in well-rounded sentences, full of interesting views and supporting material (even though there obviously were no handouts available or power point slides to look at). When he was done, Rajan then elegantly fielded some questions from the audience - altogether a totally awing feat, and all the more impressive, given the fact that it was entirely improvised, and solely supported by the rhetorical and professional capabilities of its presenter, who certainly showed his mettle, as one worthy of the epithet 'not being unafraid of Austin and his speech acts'!

To this senior scholar and friend, Professor Kanavillil Rajagopalan, this great thinker and communicator, this pragmatic mover and shaker, this indefatigable and unafraid guide through the labyrinthine world of Austinian speech acting and beyond, I raise my virtual glass in homage, and wish him a continued happy and long life of service to our community (Brazil-based and world-wide) that has done so well by him. Uniting our voices and forces in a supremely felicitous, and well-deserved, congratulatory act of speaking, we venture to say:

Dear Rajan, well done! And I wish you:

Muitos anos de êxitos linguísticos, felicidade pessoal e boa convivência social.

Recebido em novembro de 2013

Aprovado em janeiro de 2015

E-mail: jacob_mey@yahoo.com

\section{References}

FERREIRA, Lúcio Menezes. 2004. Intervenções de um linguista (Review of Rajagopalan 2003). historia e-historia, 6 September 2004. Campinas, S.P.: Unicamp.

Hall, Jr. Robert A. 1950. Leave your language alone. Ithaca, N.Y.: Linguistica.

Mey, Jacob L. 1979. Zur kritischen Sprachtheorie. In: Jacob Mey. Ed. Pragmalinguistics, theory and practice. The Hague: Mouton. pp. 411-434.

1985. Whose language? A study in linguistic pragmatics. Amsterdam: John Benjamins. 
32.3

2016

. 2002. As vozes da sociedade. Campinas, S.P.: Mercado de Letras.

2009. Adaptability in Human-Computer Interaction. In: Jacob L. Mey, ed., Concise Encyclopedia of Pragmatics. Oxford: Elsevier. pp. 7-13.

Nerlich, Brigitte \& Clarke, David D. 1994. Language, action and context: Linguistic pragmatics in Europe and America (1800-1950). Journal of Pragmatics 22: 439-463.

Rajagopalan, Kanavillil. 2000. On Searle [on Austin] on language. Language \& Communication 20: 347-391.

. 2003. Por uma linguística crítica: Linguagem, identidade e a questão ética. São Paulo: Parábola Editorial.

2005. The language issue in Brazil: When local knowledge clashes with expert knowledge. In: S. Canagarajah. Ed. Negotiating the Global and the Local in Language Policy and Practice. Mahwah, N.J.: Lawrence Erlbaum. pp. 99-132.

2010. A nova Pragmática: Fases e feições de um fazer. São

Paulo: Parábola Editorial. 